\title{
A New Land Surface Hydrology within the Noah-WRF Land-Atmosphere Mesoscale Model Applied to Semiarid Environment: Evaluation over the Dantiandou Kori (Niger)
}

\author{
B. Decharme, ${ }^{1,2}$ C. Ottlé, ${ }^{1}$ S. Saux-Picart, ${ }^{3}$ N. Boulain, ${ }^{4}$ B. Cappelaere, ${ }^{4}$ D. Ramier,,${ }^{4,5}$ \\ and M. Zribi ${ }^{6}$ \\ ${ }^{1}$ CNRS/IPSL, Laboratoire des Sciences du Climat et de l'Environnement, 91191 Gif-sur-Yvette, France \\ ${ }^{2}$ GAME/CNRM, URA 1357, CNRS-Météo-France, 31057 Toulouse, France \\ ${ }^{3}$ CNRS/IPSL, Centre d'étude des Environnements Terrestre et Planétaires, 78140 Vélizy, France \\ ${ }^{4}$ IRD/UMR HydroSciences, 34934 Montpellier, France \\ ${ }^{5}$ IRD/Niamey, Avenue de Maradi, BP11416, Niamey, Niger \\ ${ }^{6}$ IRD/CESBIO, Avenue Edouard Belin 18, BPI2801, 31401 Toulouse, France
}

Correspondence should be addressed to B. Decharme, bertrand.decharme@meteo.fr

Received 29 April 2009; Accepted 29 August 2009

Recommended by Qi Hu

Land-atmosphere feedbacks, which are particularly important over the Sahel during the West African Monsoon (WAM), partly depend on a large range of processes linked to the land surface hydrology and the vegetation heterogeneities. This study focuses on the evaluation of a new land surface hydrology within the Noah-WRF land-atmosphere-coupled mesoscale model over the Sahel. This new hydrology explicitly takes account for the Dunne runoff using topographic information, the Horton runoff using a Green-Ampt approximation, and land surface heterogeneities. The previous and new versions of Noah-WRF are compared against a unique observation dataset located over the Dantiandou Kori (Niger). This dataset includes dense rain gauge network, surfaces temperatures estimated from MSG/SEVIRI data, surface soil moisture mapping based on ASAR/ENVISAT C-band radar data and in situ observations of surface atmospheric and land surface energy budget variables. Generally, the WAM is reasonably reproduced by Noah-WRF even if some limitations appear throughout the comparison between simulations and observations. An appreciable improvement of the model results is also found when the new hydrology is used. This fact seems to emphasize the relative importance of the representation of the land surface hydrological processes on the WAM simulated by Noah-WRF over the Sahel.

Copyright (C) 2009 B. Decharme et al. This is an open access article distributed under the Creative Commons Attribution License, which permits unrestricted use, distribution, and reproduction in any medium, provided the original work is properly cited.

\section{Introduction}

The Sahel has been subject to significant droughts since the late sixties that emphasize the vulnerability of the hydrological cycle to climatic and environmental conditions. These droughts involve critical consequences on the water resources as well as on the Sahelian populations. Nevertheless, the hydrological response to climatic or environmental changes is complicated by the complexity of the terrestrial system: the severe climatic conditions, the large land cover heterogeneity (vegetation and soil) and the poor amount of data available for processes calibration. Reciprocally, the continental part of the hydrological cycle seems to impact on the West
African Monsoon (WAM). The WAM takes place during the summer months, generally from June to September. One of the key processes is the partitioning of rainfall into runoff, infiltration, soil water storage, and evapotranspiration. Since the pioneering study of Charney [1] pointing out the influence of the surface albedo on the simulated precipitation over the Sahel using an atmospheric general circulation model (AGCM), some observational and numerical studies have shown that land-atmosphere feedbacks in the WAM could be important on a wide range of spatial and temporal scales [2-5]. For example, Douville [4] has pointed out that despite the significant impact of sea surface temperature, global soil moisture could have an influence on the rainfall 
variability over West Africa. Koster et al. [5] have indicated that a strong coupling between soil moisture and rainfall anomalies could exist over this region.

The influence of the land surface on the WAM depends on a large range of processes linked to the land surface hydrology and the vegetation heterogeneities. This fact induces the necessity to develop land surface-atmosphere coupled models for a better understanding of the role of the land surface on the WAM dynamics in order to better predict its variability. On the other hand, a realistic simulation of the hydrological impacts of seasonal climate anomalies and global warming will be critical in the near future for water resources, ecology, and human activities. In this context, many efforts are underway to improve the representation of the continental hydrological cycle in numerical land surface-atmosphere-coupled models. The use of high-resolution mesoscale models represents a significant advantage compared to coarser AGCMs. In these models, the land surface is generally represented by land surface models (LSMs) with multiple parameterizations that represent physical processes linked to vegetation, soil, and snow. Today, LSMs are also used to simulate the principal mechanisms that control the evolution of the various continental fresh water reservoirs, across daily to climate change timescales.

In the present study, the Weather Research and Forecasting (WRF) model is used where the land surface is simulated via the Noah LSM [6]. WRF (http:// wrf-model.org/index.php) is a next-generation mesocale numerical weather prediction system designed to serve both operational forecasting and atmospheric research. It is partly developed by the National Center for Atmospheric Research (NCAR) and is currently in operational use at the National Center for Environmental Prediction (NCEP). The purpose of this study is to analyze the performance of Noah-WRF over the Sahel for hydrological applications using a new land surface hydrology introduced recently into the Noah LSM [7]. In this new version, the Sub-Grid Hydrology (SGH) scheme [8] is used in which a comprehensive set of hydrological parameterizations without any basin-scale calibration is represented. Noah-SGH accounts for both the infiltration excess mechanism, so-called Horton runoff, and the saturation mechanism, so-called Dunne runoff, as well as heterogeneities in land surface properties. It is important to note that Noah-SGH has already been evaluated in offline mode from regional to global scale leading to a significant improvement of the model performance, especially for simulating realistic river discharges [7].

Two experiments are performed over the Sahel in order to compare Noah-SGH with the former Noah version into WRF. The results are evaluated over Dantiandou Kori mesosite $\left(\sim 2500 \mathrm{~km}^{2}\right)$ of the AMMA-Catch observatory in the Niger. This studied area is located in southwestern Niger where a dense rain gauge network is present. To evaluate the model, satellite estimates of surface temperature and soil moisture are available as well as in situ measurements of several surface atmospheric fluxes and land surface variables. The model and the new land surface hydrology are briefly described in Section 2. The experiment design is shown in Section 3. The results are shown in Section 4 while the discussion and the main conclusions are given in Sections 5 and 6 , respectively.

\section{Model Description}

2.1. The Noah-WRF Model. The Advanced Research WRF model (ARW, version 2.2) is a non-hydrostatic model using, in this study, 28 sigma vertical levels. The microphysics is represented by the sophisticated Lin et al. [9] scheme that includes ice, snow, and graupel processes. The longwave radiations are simulated using the Rapid Radiative Transfer Model (RRTM) that accounts for trace gases and microphysics species [10] while the Dudhia [11] scheme is used to represent shortwave radiation. The Planetary Boundary Layer (PBL) is computed using the Hong and Pan [12] scheme that takes into account a countergradient flux for heat and moisture, and where the PBL height is determined from a critical bulk Richardson number. Finally, the convection is parameterized with Kain-Fritsch cumulus scheme [13] as recommended by Gilliland and Rowe [14].

Noah is a relatively simple LSM and the following description corresponds to the control version (CTL) of this study. It has a multilayer soil hydrology using four soil layers with a top-layer thickness of $10 \mathrm{~cm}$ and a uniform total soil depth of $2 \mathrm{~m}$. It solves explicitly vertical soil water transport using the diffusive form of Richards' equation $[6,15]$ as well as Brook and Corey [16] power relationships between soil hydraulic conductivity, water matric potential, and volumetric soil moisture in each layer. The infiltration rate is computed as the difference between the surface runoff and the through-fall rate, which is the sum of the rainfall not intercepted by the canopy, the dripping from the interception reservoir, and the snowmelt. The surface runoff is calculated using a Simple Water Balance (SWB) scheme [17] This scheme has been previously developed for a two-reservoir hydrological model typically calibrated for large river basins. SWB is a storage-type water balance scheme that accounts for the spatial variability in precipitation and soil moisture. It depends on total soil moisture and on two constants that are specified based on the PILPS-2(c) experiments over North-America [18]. As mentioned by Chen and Dudhia [6], further work should be needed to calibrate the SWB scheme parameters over various regions with different precipitation climatologies and land surface states, which represents a significant limitation for hydrological applications over specific regions as the Sahel.

2.2. Brief Review of Noah-SGH. The new version of Noah (named PHY) tested in this study corresponds to Noah-SGH generally used at the regional and global scale. More details can be found in Decharme et al. [8] and Decharme [7]. First, the vertical hydrology has been improved compared to CTL. 
In Noah, the bare soil evaporation, $E_{g}\left(\mathrm{~kg} \cdot \mathrm{m}^{-2} \cdot \mathrm{s}^{-1}\right)$, is calculated as follows [15]:

$$
\begin{aligned}
& E_{g}=(1-\mathrm{veg}) h_{u} E_{p}, \\
& h_{u}=\left(\frac{w_{1}-w_{\mathrm{dry}}}{w_{\mathrm{sat}}-w_{\mathrm{dry}}}\right)^{2},
\end{aligned}
$$

where $E_{p}\left(\mathrm{~kg} \cdot \mathrm{m}^{-2} \cdot \mathrm{s}^{-1}\right)$ is the potential evaporation, $h_{u}$ the surface relative humidity, veg the greenness fraction of vegetation over the grid-cell, $w_{1}\left(\mathrm{~m}^{3} \cdot \mathrm{m}^{-3}\right)$ the soil moisture of the first layer, $w_{\text {sat }}\left(\mathrm{m}^{3} \cdot \mathrm{m}^{-3}\right)$ the soil porosity, and $w_{\text {dry }}\left(\mathrm{m}^{3} \cdot \mathrm{m}^{-3}\right)$ a dry soil moisture threshold (equal to 0.002 in this study) where $E_{g}$ ends. In order to more properly represent the influence of soil moisture on $E_{g}, h_{u}$ has been changed from this simple power formulation to a cosine expression as recommended by Mahfouf and Noilhan [19]:

$$
h_{u}=\frac{1}{2}\left[1-\cos \left(\pi \frac{w_{1}-w_{\mathrm{dry}}}{w_{\mathrm{sat}}-w_{\mathrm{dry}}}\right)\right] .
$$

In addition, to account for the larger soil moisture gradient near the surface, seven soil layers are used instead of four in which the $10 \mathrm{~cm}$ original top layer is replaced by three fine layers $(1 \mathrm{~cm}, 3 \mathrm{~cm}$, and $6 \mathrm{~cm})$ while the three other deeper layers are replaced by four new layers. The thicknesses of each layer depend on total soil depth computed for each vegetation type (from $2 \mathrm{~m}$ for grassland, cropland, shrubland, or savana to $5 \mathrm{~m}$ for Evergreen Forest). An exponential profile with soil depth of the saturated hydraulic conductivity, $k_{\text {sat }}$, is assumed within the soil column. This profile depends only on two parameters, which represent the rate of decline of the $k_{\text {sat }}$ profile and the depth where $k_{\text {sat }}$ reaches its so-called "compacted value." The first parameter is related to soil properties [8, equation (11)] and the second is assumed to be equal to the rooting depth. This parameterization allows an increase (high $k_{\text {sat }}$ ), or a decrease (low $k_{\text {sat }}$ ), in soil water transport near the surface, or more deeply, compared to the previous representation with a homogeneous soil. Sensitivity tests and a detailed discussion regarding this approach can be found in Decharme et al. [8]. Last, a simple vapour diffusivity scheme has been introduced to reproduce the upward soil water transport in vapour phase that can be important over arid or semiarid regions [20].

Secondly, both Horton and Dunne runoff, as well as heterogeneities in land surface properties are taken into account. Land cover and soil depth heterogeneities are represented using a tile approach in which each grid cell is divided into a series of subgrid patches. This method has the advantage of explicitly representing very distinct surface types with specific properties. Each subgrid patch extends vertically throughout the soil-vegetation-snow column. The relative grid cell fractional coverage of each tile is used to determine the grid box average of the water and energy budgets.

The Dunne runoff is computed via a TOPMODEL approach that attempts to combine the important distributed effects of channel network topology and dynamic contributing areas for runoff generation [21]. This formalism takes into account topographic heterogeneities explicitly by using the spatial distribution of the topographic indices, $\lambda_{i}(\mathrm{~m})$, in each grid-cell defined as follows:

$$
\lambda_{i}=\ln \left(\frac{a_{i}}{\tan \beta_{i}}\right),
$$

where $a_{i}(\mathrm{~m})$ is the drainage area per unit of contour of a local pixel, $i$, and $\tan \beta_{i}$ is the local surface slope that approximates the local hydraulic gradient. If the pixel has a large drainage area and a low local slope, its topographic index will be large and thus, its ability to be saturated will be high. Then, this topographic index can be related to a local water deficit [22], and using the spatial distribution of the topographic indices over the grid cell, a saturated fraction, $f_{\text {sat }}$, inversely proportional to the grid cell mean deficit, can be defined. More details can be found in Decharme et al. [8] and Decharme [23]. The Dunne runoff, $Q_{D}\left(\mathrm{~kg} \cdot \mathrm{m}^{-2} \cdot \mathrm{s}^{-1}\right)$, is thus simply given by $Q_{D}=P_{g} \times f_{\text {sat }}$, where $P_{g}\left(\mathrm{~kg} \cdot \mathrm{m}^{-2} \cdot \mathrm{s}^{-1}\right)$ is the throughfall rate. Note that in the TOPMODEL approach used within the SGH scheme, all parameters are solely dependant on soil properties [7, 8]. Therefore, this approach does not require any calibration, a significant advantage for hydrological applications compared to the SWB scheme. Note that a high-resolution $(40 \mathrm{~m})$ digital elevation model is used over Dantiandou Kori to derived the topographic indexes.

Finally, the Horton runoff is computed using a maximum infiltration capacity function, $I_{\max }\left(\mathrm{kg} \cdot \mathrm{m}^{-2} \cdot \mathrm{s}^{-1}\right)$ [7]. The maximum infiltration rate is given by a Green-Ampt model approximation according to Abramopoulos et al. [24] and Entekhabi and Eagleson [25]:

$$
I_{\max }=\rho_{w} k_{\text {sat }}(0)\left[\frac{b \psi_{\text {sat }}}{\Delta z}\left(\frac{w_{10}}{w_{\text {sat }}}-1\right)+1\right],
$$

where $\rho_{w}\left(\mathrm{~kg} \cdot \mathrm{m}^{-3}\right)$ is the water density, $k_{\mathrm{sat}}(0)\left(\mathrm{m} \cdot \mathrm{s}^{-1}\right)$ the surface saturated hydraulic conductivity, $\psi_{\text {sat }}(\mathrm{m})$ the saturated soil water potential or air entry potential, $\Delta \mathrm{z}(\mathrm{m})$ the soil thickness of $10 \mathrm{~cm}$, and $b$ the dimensionless slope of the soil moisture retention curve $[16,26]$. Also, $w_{10}\left(\mathrm{~m}^{3}\right.$. $\mathrm{m}^{-3}$ ) represents the mean soil moisture over the first ten centimeters. The first ten centimeters are used instead of the very fine first layer in order to prevent the drastic ability of this first layer to be saturated during a rainy event whatever the model horizontal spatial scale (from the kilometer at the mesoscale to a more coarse resolution at the regional or global scale). According to this formalism, the surface runoff, $\mathrm{Q}_{s}\left(\mathrm{~kg} \cdot \mathrm{m}^{-2} \cdot \mathrm{s}^{-1}\right)$, is computed as follows:

$$
Q_{s}=Q_{D}+\left(1-f_{\text {sat }}\right) \max \left(0, P_{g}-I_{\max }\right) .
$$

\section{Experiment Design}

3.1. Experiments. The Noah-WRF model is implemented over a part of West-Africa and it is configured with three nested grids in a two-way mode (Figure 1). The largest grid (grid 1) covers an area of $\sim 2.10^{6} \mathrm{~km}^{2}$, the second (grid 2) $48600 \mathrm{~km}^{2}$ and the third (grid 3) which represents the 


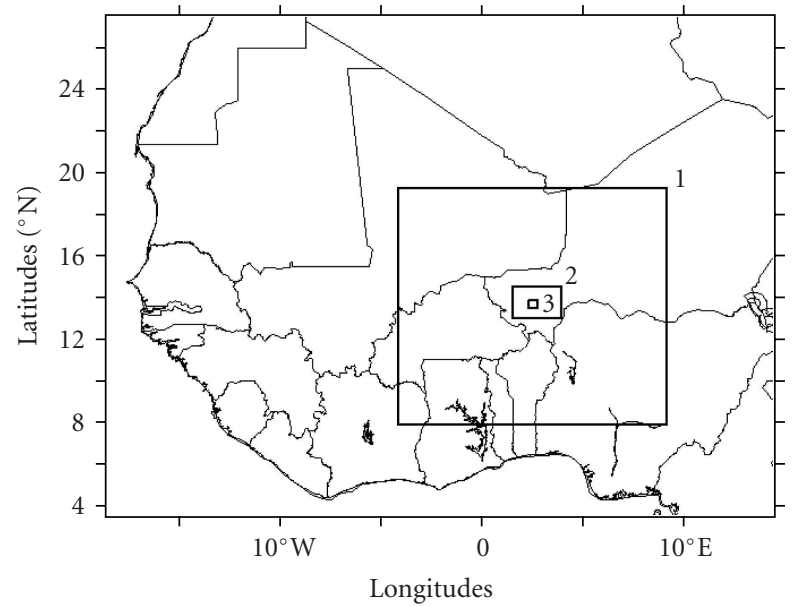

Figure 1: The full experimental domain over West Africa where Noah-WRF is applied in nesting mode. The two coarse grids ( 1 and 2) used in this study are shown as well as Dantiandou Kori (grid 3, the evaluation domain).

evaluation domain named Dantiandou Kori with an area of $2430 \mathrm{~km}^{2}$. The spatial and temporal resolution of each grid is defined as follows:

(i) grid 1: $45 \mathrm{~km}$ grid-scale resolution with a 225 -second time step,

(ii) grid 2: $9 \mathrm{~km}$ grid-scale resolution with a 45 -second time step,

(iii) grid 3 (evaluation domain): $3 \mathrm{~km}$ grid-scale resolution with a 15 -second time step.

The same atmospheric and land surface physics are used in each domain. Note that even at $3 \mathrm{~km}$ resolution the KainFritsch convection parameterization is activated. Preliminary tests have shown that no explicit convection was resolved by the model during the WAM even at this scale. The purpose of the two coarse domains (grid 1 and 2) is to downscale the synoptic-scale back-ground flow to appropriate boundary conditions for the finest grid. In addition, they push the model lateral boundaries condition to a much greater distance from the region of interest (grid 3).

The large-scale lateral boundary conditions (pressure, wind, temperature, and humidity) are provided by the NCEP Final Analysis (FNL, ds083.2) over more than 2 years (from July 2004 to December 2006), on 6-hour time step and at $1^{\circ}$ resolution. The two following simulations are performed starting from the same initial conditions of soil temperatures and soil moisture using NCEP FNL data at the first of July 2004 and the period from 2005 to 2006 is used at the evaluation stage:

(i) CTL: the control experiment using the Noah-WRF former version,

(ii) PHY: this experiment is performed using the new land surface hydrology (Noah-SGH).
Land surface characteristics are specified using the WRF default United States Geological Survey (USGS) data. In grids 1 and 2, these data are given at a 2 arc minute $(\sim 3 \mathrm{~km})$ resolution while 30 arc second $(\sim 1 \mathrm{~km})$ are used in grid 3 . The greenness vegetation fractions in each grid cell are provided by the NCEP FNL data at $1^{\circ}$ resolution. These data vary from $1 \%$ in the north to $80 \%$ in the south of grid cell area in grid $1,1 \%$ to $11 \%$ in grid 2 and $1 \%$ to $2.6 \%$ in grid 3 . In the region of interest (grid 3), the soil parameters are spatially homogenous corresponding to a sandy loamy soil. The vegetation parameters are mainly related to grassland and, to a lesser extent, to savanna even if some small fractions of cropland and shrubland are present. The related Leaf Area Index (LAI) are time invariant (3.22 for grassland and cropland, 3.02 for shrubland, and 1.38 for savanna) and certainly not realistic for the Sahel [27]. Finally, in grids 1 and 2, the topographic indexes are given at a $1 \mathrm{~km}$ resolution using the HYDRO1K dataset (http://edcdaac.usgs.gov/gtopo30/hydro/) while over the studied area (grid 3), a finer digital elevation model at $40 \mathrm{~m}$ resolution is used to derived these indexes [28].

3.2. Evaluation Datasets. Dantiandou Kori (grid 3) is close to Niamey and the center of HAPEX-Sahel's square degree $\left(2-3^{\circ} \mathrm{E}, 13-14^{\circ} \mathrm{N}\right)[29]$. Over this area, the simulations are evaluated against the dense AMMA-Catch Niger rain gauge network $[30,31]$ of the French Institut de Recherche pour le Développement (IRD). More than 13 stations are available at a 5 minutes time step over the studied area. These rainfall amounts are spatially distributed using a simple barycentric interpolation method. Each domain grid-cell is reached by a precipitation that is equal to the average rainfall of the three closest gauges weighted by the inverse of the distance between the considered grid-cell and each gauge. This method has the advantage to less smooth extreme rainy events than simple kriging interpolations [32].

In addition, simulated surface temperatures are compared to the remote sensing Meteosat Second Generation/Spinning Enhanced Visible and Infra Red Imager (MSG/SEVIRI) data where the surface temperatures are estimated using a Split-Window algorithm accounting for land surface emissivity, atmospheric water vapour, and satellite viewing angle [33]. The Land Surface Temperature (LST) product is provided by the Eumetsat/SAF Land via the POSTEL Land Surface Thematic Center (http://postel.mediasfrance.org/). Note that the product is available only in clear sky conditions, a wavelet transform filtering has been applied to eliminate the cloudy data [27]. The dataset covers the time period from July 2005 to December 2006 at $3 \mathrm{~km}$ resolution with a $15 \mathrm{mn}$ time step.

Surface soil moisture estimations derived from ASAR/ENVISAT C-band radar instrument are also used to evaluate the simulation. Soil moisture data are provided at high resolution $(12.5 \mathrm{~m})$ and only for field with bare-soil or low-density vegetation, using low-incidence-angle radar data (ISI configuration). The comparison between in situ measurements and these data has shown very good results. More details can be found in Zribi et al. [34]. Over 2005, 13 


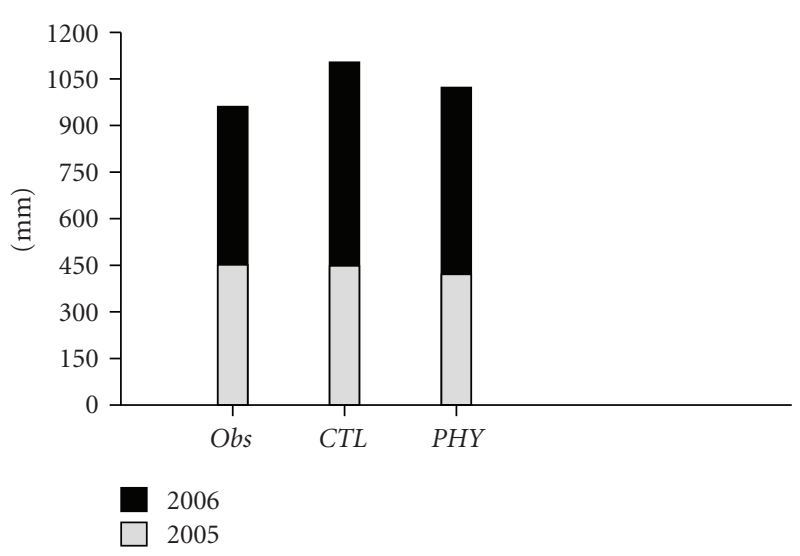

(a) 2 years cumulated precipitations.

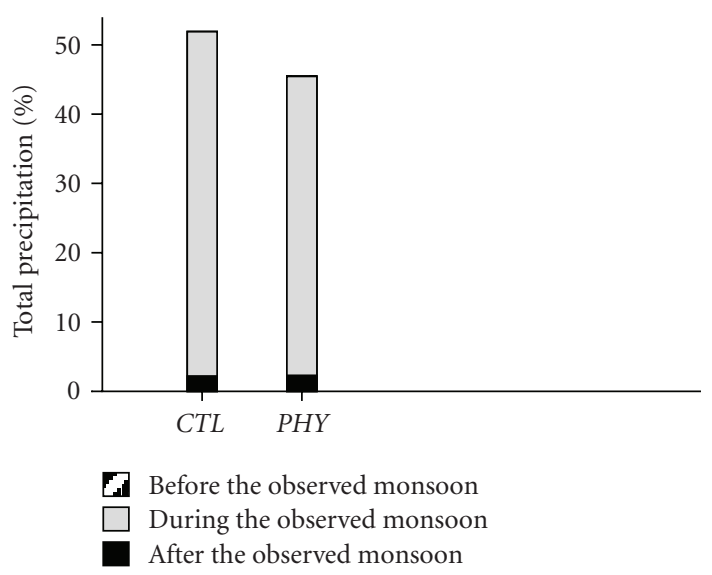

(b) The amount of annual precipitation simulated but not observed.

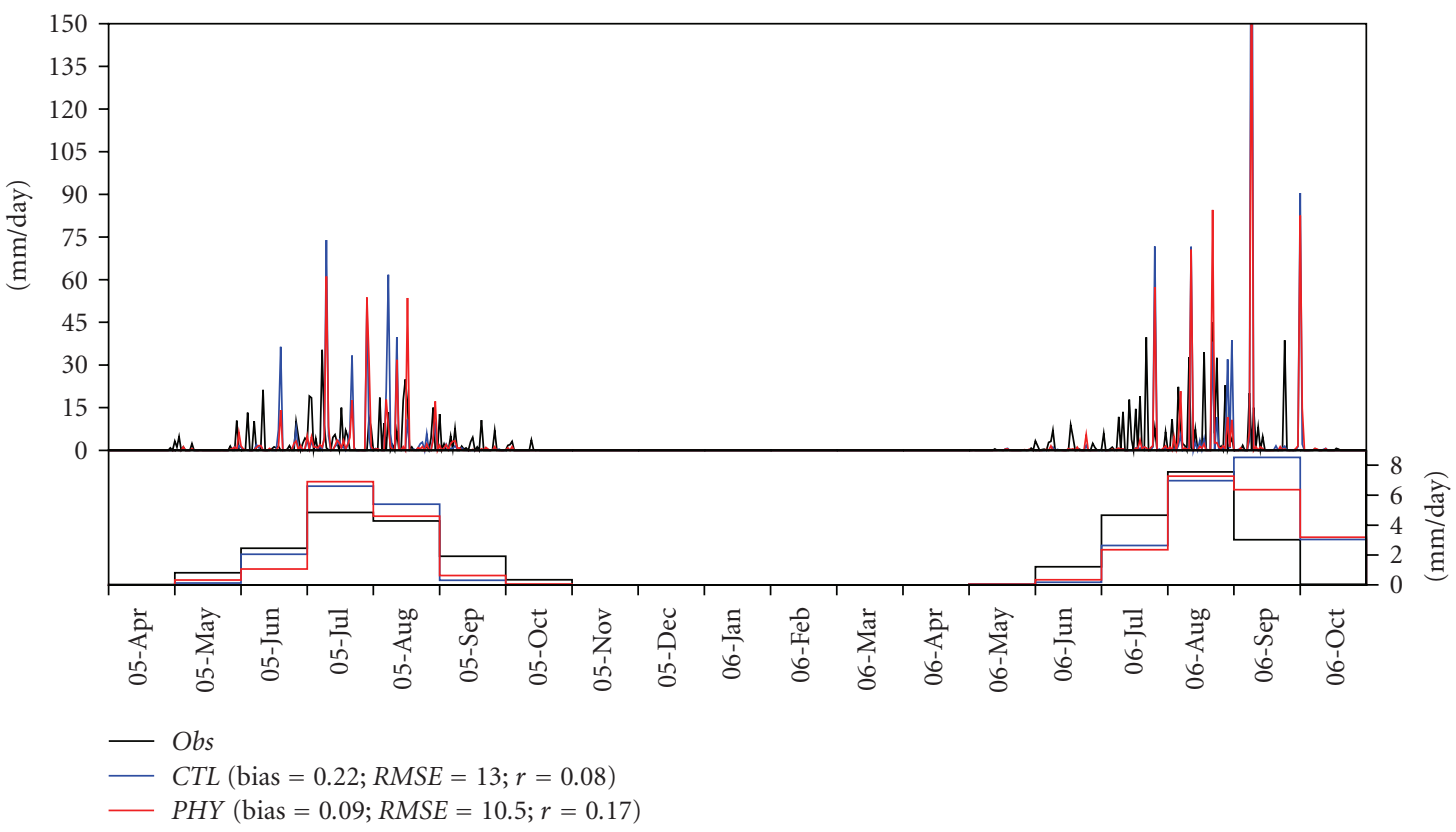

(c) Time series of daily and monthly precipitations ( $\mathrm{mm} /$ day).

FIGURE 2: Domain average comparison between simulated and observed precipitation over Dantiandou Kori: (a) the cumulated annual precipitation rate $(\mathrm{mm})$ simulated by each experiment; (b) the ratio to annual precipitation of daily precipitation simulated by each experiment but not observed, expressed in \%, distinctions are made for precipitations that are simulated before, during and after the observed monsoon season; (c) the times series of simulated and observed monthly and daily precipitations (mm/day). The observations are in black, CTL in blue and PHY in red. The daily biases, the root mean square errors (RMSE) and the correlations ( $r)$ are also given for each experiment.

soil moisture maps were produced over Dantiandou Kori from February 17 to September 15. The ASAR data have been aggregated to the $3 \mathrm{~km}$ resolution and the grid cells where less than $30 \%$ of the data are not available have been masked.

Finally, the WRF results are also compared to in situ measurements of surface atmospheric variables (longwave and shortwave radiations, $2 \mathrm{~m}$ air temperature, relative humidity, wind speed, and precipitation) and land surface energy fluxes (surface net radiation, ground, latent, and sensible heat fluxes). These measurements were acquired at the Wankama stations in the Fakara watershed $\left(\sim 2.6^{\circ} \mathrm{E}\right.$, $\sim 13.6^{\circ} \mathrm{N} ; \sim 3 \mathrm{~km}^{2}$ ) $[35,36]$. Two $\mathrm{CO}_{2} / \mathrm{H}_{2} \mathrm{O}$ flux stations, distant by approximately $1 \mathrm{~km}$ and corresponding to a fallow and a millet sites, have been settled to characterize the heat, evapotranspiration, and carbon dioxide fluxes [37]. These sets of observations were acquired starting from 16 June 2005 and ending on 31 December 2006 at a 30 minute time step. The two stations are $1 \mathrm{~km}$ distant and the measured fluxes are very close. Consequently, for this study the two stations have been averaged in order to directly compare each observed variable with the corresponding WRF grid cell results. Note 


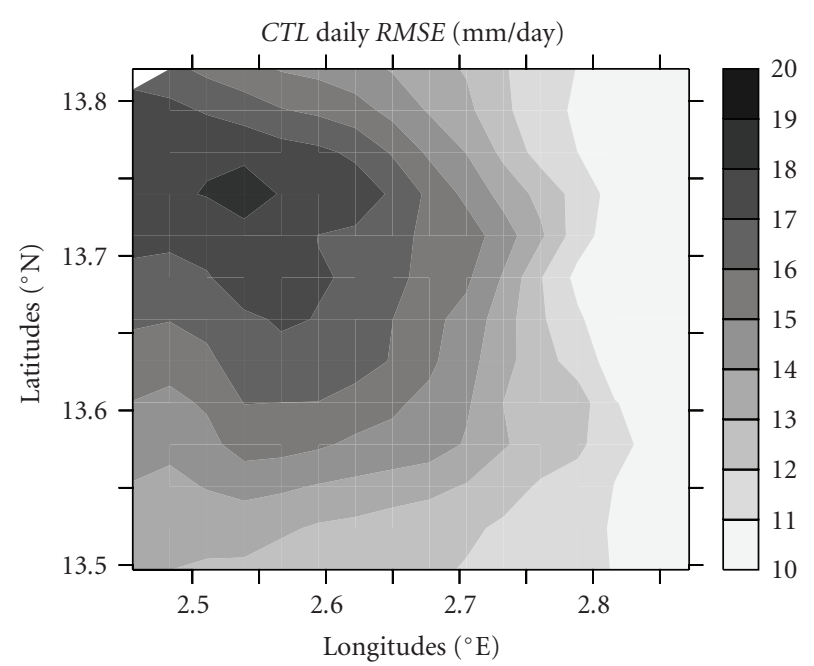

(a)

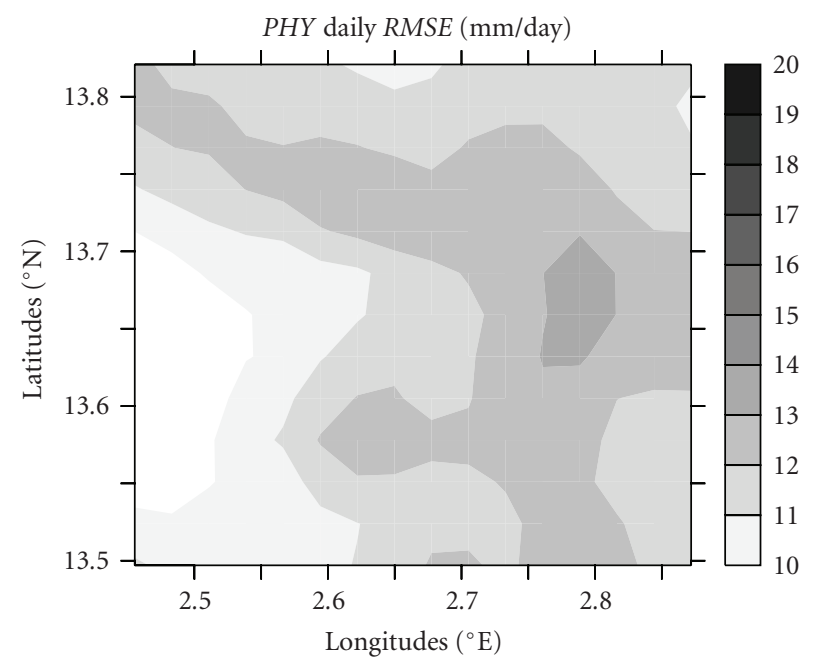

(c)

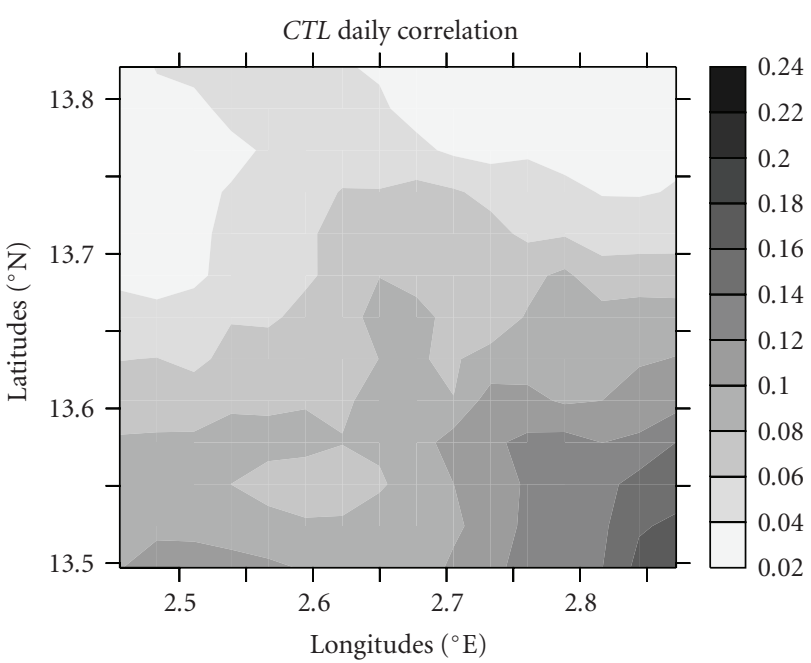

(b)

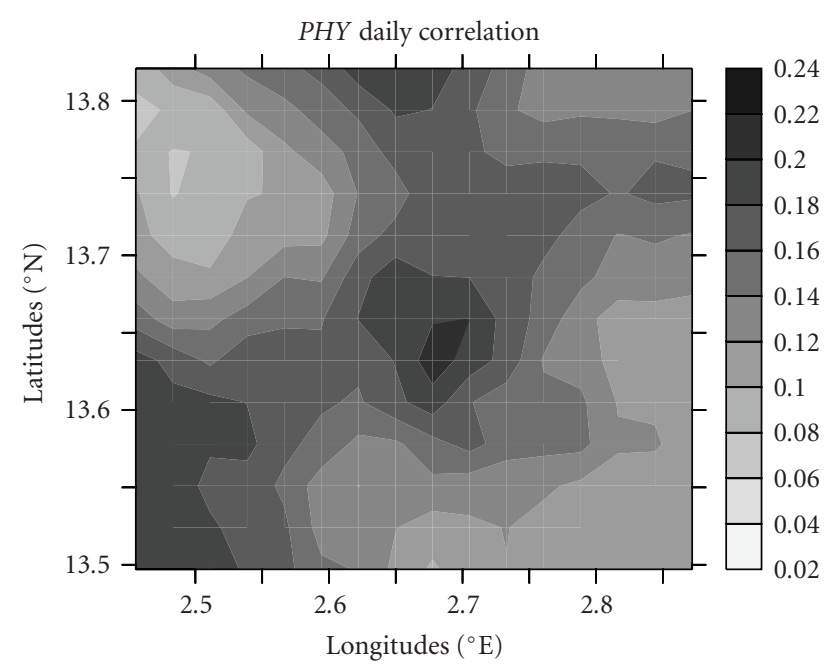

(d)

FIGURE 3: Statistical comparison (RMSE and correlation) between simulated and observed daily precipitations over Dantiandou Kori.

that because wind speed is simulated at $10 \mathrm{~m}$ by WRF, the observed wind speed at 7,8 $\mathrm{m}$ is extrapolated to $10 \mathrm{~m}$ via the classical logarithmic wind profile assumption.

\section{Results}

4.1. Evaluation over the Diantandou Kori. Figure 2 compares the domain (grid 3) average simulated and observed precipitation. In both experiments, Noah-WRF generally simulates more precipitation than in the observations, especially in 2006 (Figure 2(a)). This kind of overestimation is generally seen in mesoscale modeling over the Sahel $[38,39]$. Figure 2(b) shows the ratio of daily precipitation simulated but not observed to the annual precipitation:

$$
P_{\text {sim_notobs }}=100 \times \frac{\sum\left(P_{\text {sim }}^{i}, \forall P_{\mathrm{obs}}^{i}=0\right)}{\sum P_{\text {sim }}^{i}},
$$

where $P_{\text {sim }}^{i}$ and $P_{\text {obs }}^{i}$ are the daily simulated and observed precipitation. Results show that this amount of precipitation that is simulated but not observed is important, especially during the WAM season (from June to September). Only the half of the precipitation simulated during the whole experimental period matches the observations. This finding mainly explains the large root mean square errors (RMSEs) and the poor correlations $(r)$ observed on the daily time series given in Figure 2(c). It must be underlined that a regional climate model like WRF is unlikely to get the exact timing of precipitation events during the course of a season or longer. In addition, the model shows a tendency to simulate some extreme daily rainy events during the WAM (Figure 2(c)). On the other hand, the WAM period is reasonably reproduced because only $\sim 2.2 \%$ of the precipitation is simulated after the observed monsoon (Figure $2(\mathrm{~b})$ ), principally in 2006 (Figure 2(c)). The monthly means in Figure 2(c) point out that Noah-WRF generally underestimates precipitation at the beginning of the monsoon season while the end of the 


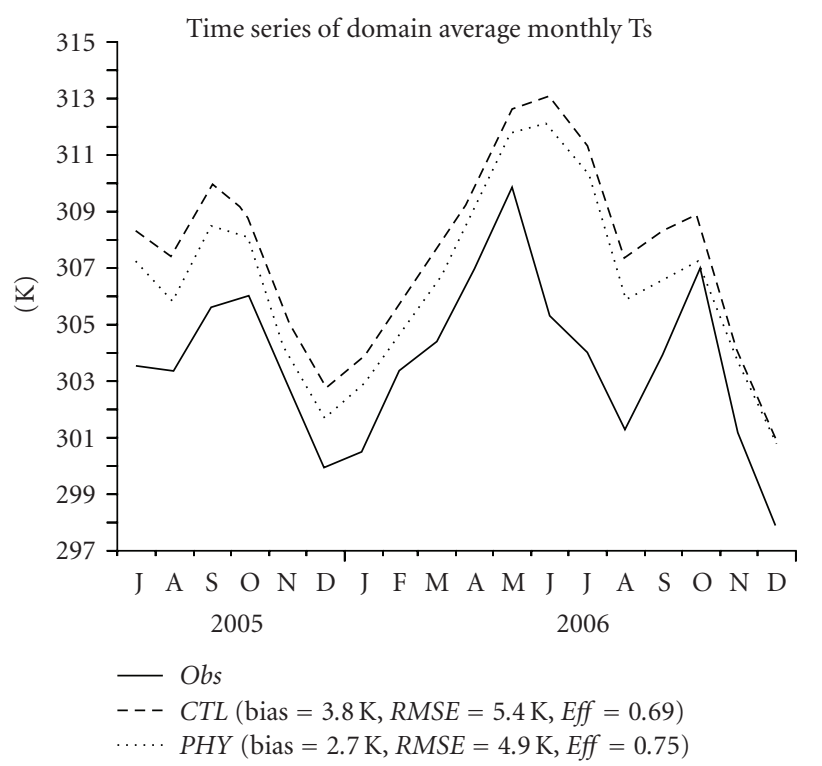

FIgure 4: Comparison between the simulated and MSG/SEVIRI estimated monthly surfaces temperatures over Dantiandou Kori. The Bias, RMSE, and Efficiency (Eff) statistics calculated at a 3-hour time step are also given.

season is more contrasted between 2005 and 2006. In 2005, the season length is underestimated, especially in September, while in 2006 an intense rainy event is simulated in the beginning of October, approximately 10 days after the last observed event.

Comparing the $P H Y$ experiment to $C T L$, Figure 2 shows that the annual bias and the amount of annual precipitation simulated but not observed (52\% in CTL and 45\% PHY), are reduced. $P H Y$ simulates also less severe daily rainy events during the WAM. Beside the statistics given in Figure 2(c), Figure 3 presents the spatial distribution over Dantiandou Kori of daily RMSE and correlation for each simulation. This comparison between simulated and observed precipitation confirms that the daily rainfall variability in $P H Y$ is also relatively improved.

Figure 4 compares the monthly simulated surfaces temperatures and MSG/SEVIRI estimates for the 2005-2006 period. It shows that the surface temperatures are generally overestimated by Noah-WRF. This bias is more obvious in 2006 than in 2005 especially during the WAM season. Beside this bias, the 3-hour RMSE and efficiency (Eff) [40] confirm that Noah-WRF captures the seasonal and also the diurnal cycles of the surface temperature. In addition, these figures point out that the bias is less important in PHY than in CTL and that the surface temperature dynamics is improved.

The simulated first $10 \mathrm{~cm}$ soil moisture is compared to ASAR estimates acquired in 2005 over the whole Dantiandou kori. The domain average biases are shown in Figure 5 for each ASAR image. During the dry season (February and March), PHY shows a good agreement with ASAR surface soil moisture while CTL appears too wet. During the WAM, even if $P H Y$ overestimates ASAR estimates, it shows significantly better results than CTL.

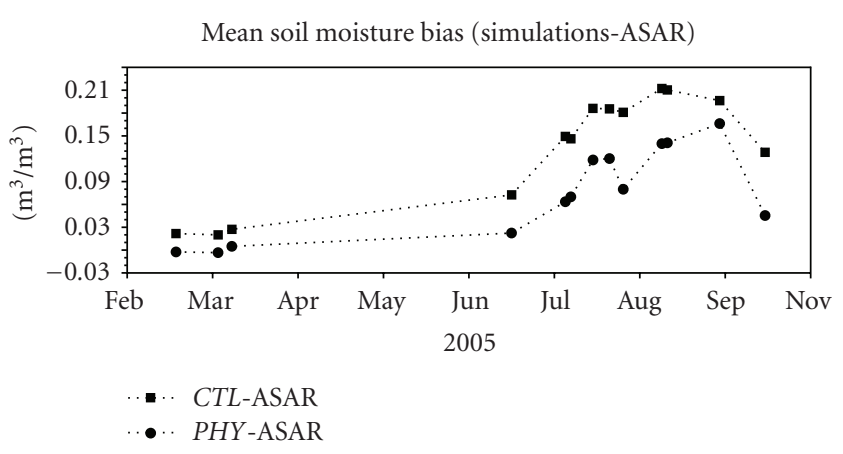

FIGURE 5: Comparison between surface soil moisture simulated and estimated from ASAR radar data. The domain average bias between the simulations and each ASAR image over Dantiandou Kori are shown.

Finally, the comparison of the water budget between CTL and PHY (Figure 6(a)) shows that the partitioning of precipitation between evapotranspiration and runoff is significantly different. In $P H Y$, the total evapotranspiration $(\sim 61 \%$ of precipitation) is more important than runoff $(\sim 17 \%)$ while this partition is more balanced for CTL $(38 \%$, $39 \%)$. Figure 6(b) also points out that total evapotranspiration is more important in $P H Y$ than in CTL during the WAM. Over semiarid environments, the evapotranspiration represents the major component of the rainfall as it is also found by Saux-Picart et al. [27] with the SEtHyS_Savannah model applied in offline mode over the same domain. This increase in evapotranspiration from CTL to $P H Y$ is due to an increase in bare soil evaporation, more related to the introduction of the $k_{\text {sat }}$ profile than to the change in surface relative humidity, $h_{u}$. The exponential profile of the saturated hydraulic conductivity with soil depth favors indeed infiltration and consequently evapotranspiration and contributes to decrease the surface runoff compared to an homogeneous profile. As it was shown in detail by Decharme et al. [8], an increase of $k_{\text {sat }}$ from the rooting depth to the surface (related to CTL) favors upward water fluxes to the surface and then bare soil evaporation. Another finding is linked to the representation of the surface runoff. In $C T L$, during a rainy event, the SWB scheme always allows surface runoff with respect to soil moisture conditions but it neglects land surface characteristics. In PHY, the use of a TOPMODEL approach allows to simulate a Dunne runoff using soil moisture and topographic information. Over Dantiandou Kori, there are some important areas of plateaux and hillslopes [27] where Dunne runoff is never generated. This process also contributes to decrease the simulated surface runoff compared to CTL.

4.2. Local Evaluation against the Wankama In Situ Measurements. Figure 7 shows the monthly comparison between in situ and simulated surface atmospheric variables over Wankama. All related 3-hour statistics are given in Table 1, except for precipitation scores calculated at a daily time scale. The simulated downward shortwave and longwave radiations appear significantly overestimated compared to 


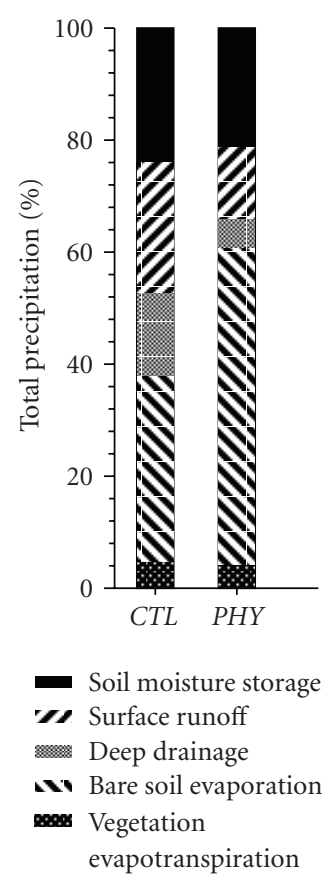

(a) Water budget

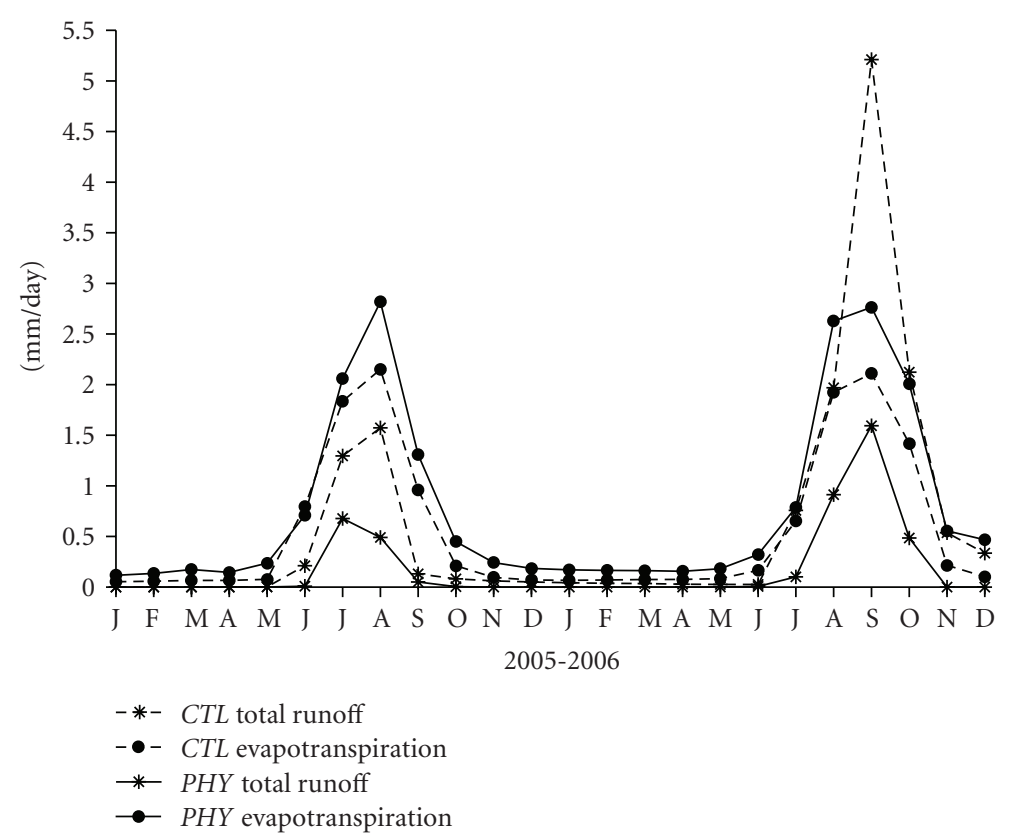

(b) Time series of monthly total runoff and evapotranspiration

Figure 6: The 2005-2006 simulated water budgets over Dantiandou Kori: (a) each water budget component is expressed in \% of total precipitations for each experiment; (b) time series of the domain average monthly total runoff and evapotranspiration.

TABle 1: Simulated surface atmospheric variables versus in situ measurements in Wankama: Precipitation, $P$ (mm/day); Relative humidity, $R h(\%) ; 2 \mathrm{~m}$ air temperature, $T a(\mathrm{~K})$; downward Shortwave, $S W$, and Longwave, $L W$, radiations $\left(\mathrm{W} / \mathrm{m}^{2}\right)$; Wind speed, $W s(\mathrm{~m} / \mathrm{s})$. The Mean, standard deviation $(\sigma)$, Bias, RMSE, correlation $(r)$, and efficiency $($ Eff) are given for all variables at a 3-hour time step, excepted for precipitation (daily).

\begin{tabular}{|c|c|c|c|c|c|c|c|c|c|}
\hline Variables & Obs & $\sigma_{o b s}$ & Exp & Mean & $\sigma$ & Bias & RMSE & $r$ & Eff \\
\hline \multirow{2}{*}{$P$} & \multirow{2}{*}{1.73} & \multirow{2}{*}{6.92} & $C T L$ & 2.37 & 15.70 & 0.64 & 16.6 & 0.08 & -4.80 \\
\hline & & & PHY & 1.96 & 11.94 & 0.23 & 12.6 & 0.18 & -2.36 \\
\hline \multirow{2}{*}{$R h$} & \multirow{2}{*}{38.74} & \multirow{2}{*}{28.06} & CTL & 30.68 & 22.39 & -8.05 & 13.6 & 0.93 & 0.77 \\
\hline & & & PHY & 35.39 & 25.83 & -3.35 & 10.3 & 0.94 & 0.86 \\
\hline \multirow{2}{*}{$\mathrm{Ta}$} & \multirow{2}{*}{302.33} & \multirow{2}{*}{5.23} & CTL & 304.27 & 4.90 & 1.94 & 3.2 & 0.88 & 0.64 \\
\hline & & & $P H Y$ & 303.49 & 4.93 & 1.16 & 2.8 & 0.88 & 0.71 \\
\hline \multirow{2}{*}{ SW } & \multirow{2}{*}{245.14} & \multirow{2}{*}{327.25} & CTL & 270.25 & 370.24 & 25.10 & 149.7 & 0.92 & 0.79 \\
\hline & & & PHY & 272.73 & 371.14 & 27.58 & 143.7 & 0.93 & 0.81 \\
\hline \multirow{2}{*}{$L W$} & \multirow{2}{*}{382.32} & \multirow{2}{*}{40.49} & CTL & 399.64 & 39.75 & 17.32 & 25.6 & 0.89 & 0.60 \\
\hline & & & PHY & 398.33 & 38.64 & 16.02 & 24.4 & 0.89 & 0.64 \\
\hline \multirow{2}{*}{$W s$} & \multirow{2}{*}{3.08} & \multirow{2}{*}{1.71} & $C T L$ & 3.53 & 1.44 & 0.45 & 2.0 & 0.26 & -0.34 \\
\hline & & & PHY & 3.46 & 1.42 & 0.39 & 1.9 & 0.29 & -0.26 \\
\hline
\end{tabular}

observations that seem to highlight a general warm bias of the model. This fact is confirmed by the overestimation of the $2 \mathrm{~m}$ air temperature which is slightly reduced in $P H Y$. Note that these biases are more pronounced during the WAM and especially in 2006. The simulated precipitation over Wankama in each experiment shows that the rainy season is shorter than observed for 2005, while a delay of 20 days is observed at the beginning and at the end of the 2006 rainy season. In addition, the daily statistics (Table 1) confirm the results described over Dantiandou Kori: the simulated precipitation is overestimated and the temporal variability is poorly represented even if a relative improvement is observed in $P H Y$. This improvement is linked with a better simulation of the atmospheric relative humidity. The wind speed is overestimated in each simulation which is found as a recurrent weakness in many mesocale models [39].

Figure 8 compares 10-day averaged observed and simulated land surface energy budgets. For the latent and sensible heat fluxes, only periods where there are at least 5 complete 


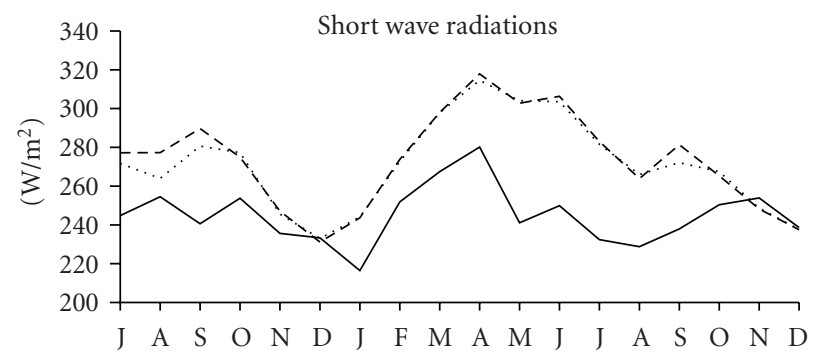

(a)

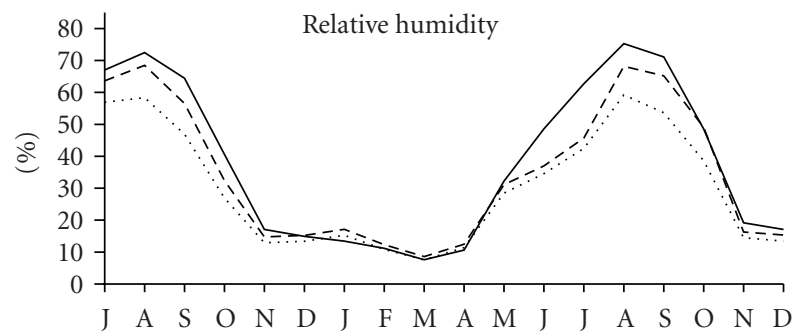

(c)

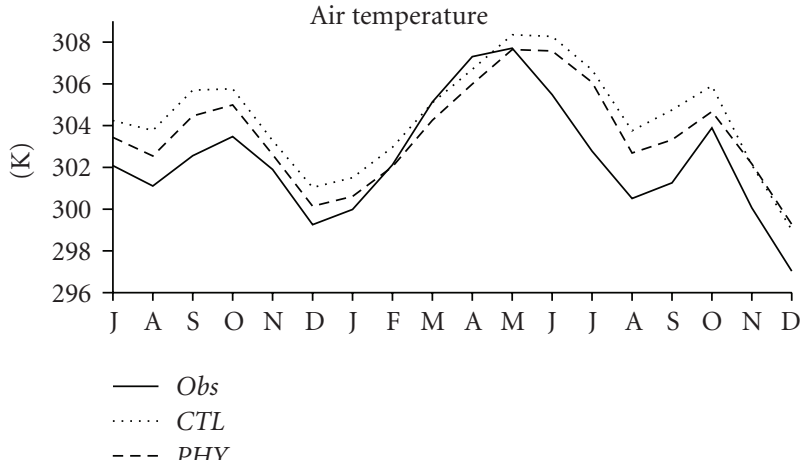

(e)

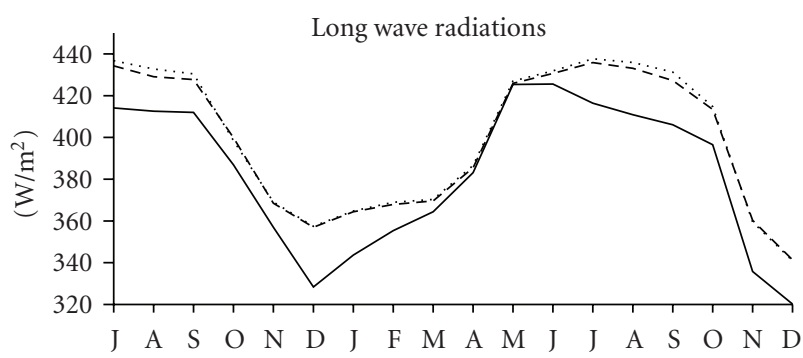

(b)

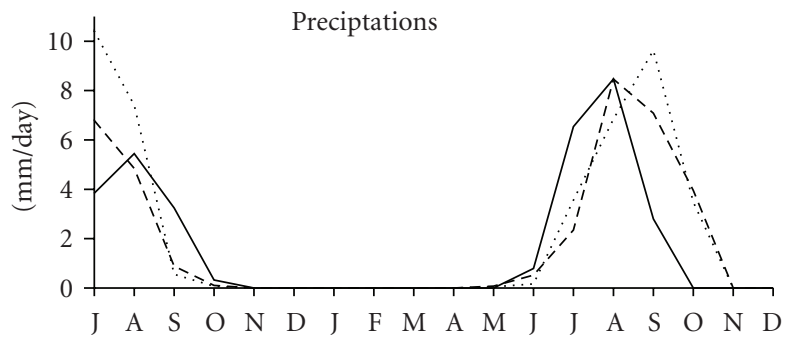

(d)

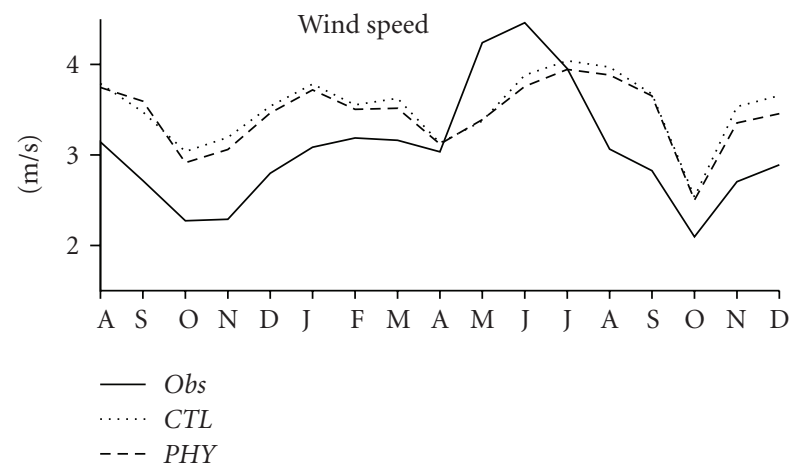

(f)

FIGURE 7: Monthly comparison between in-situ and simulated surface atmospheric variables over the Wankama watershed. All related statistics are given in Table 1.

TABle 2: As in Table 1 but for the surface energy budget variables: surface net radiation, $R n\left(\mathrm{~W} / \mathrm{m}^{2}\right)$; ground heat flux, $G\left(\mathrm{~W} / \mathrm{m}^{2}\right)$; latent heat flux, $L E\left(\mathrm{~W} / \mathrm{m}^{2}\right)$; sensible heat flux, $H\left(\mathrm{~W} / \mathrm{m}^{2}\right)$.

\begin{tabular}{|c|c|c|c|c|c|c|c|c|c|}
\hline Variables & $\mathrm{Obs}$ & $\sigma_{o b s}$ & $\operatorname{Exp}$ & Mean & $\sigma$ & Bias & RMSE & $r$ & Eff \\
\hline \multirow{2}{*}{$R n$} & \multirow{2}{*}{70.12} & \multirow{2}{*}{182.38} & $C T L$ & 116.87 & 233.48 & 46.75 & 98.6 & 0.94 & 0.71 \\
\hline & & & PHY & 126.96 & 231.88 & 56.84 & 101.2 & 0.95 & 0.69 \\
\hline \multirow{2}{*}{$H$} & \multirow{2}{*}{33.98} & \multirow{2}{*}{60.98} & $C T L$ & 96.42 & 136.97 & 62.44 & 108.8 & 0.87 & -2.18 \\
\hline & & & PHY & 92.40 & 136.24 & 58.42 & 106.4 & 0.86 & -2.05 \\
\hline \multirow{2}{*}{$L E$} & \multirow{2}{*}{56.35} & \multirow{2}{*}{79.17} & $C T L$ & 36.50 & 51.34 & -19.85 & 55.7 & 0.75 & 0.51 \\
\hline & & & PHY & 50.44 & 74.26 & -5.91 & 54.6 & 0.76 & 0.52 \\
\hline \multirow{2}{*}{ G } & \multirow{2}{*}{2.88} & \multirow{2}{*}{54.50} & CTL & -0.41 & 78.62 & -3.29 & 48.2 & 0.80 & 0.22 \\
\hline & & & PHY & -0.40 & 72.55 & -3.28 & 47.1 & 0.76 & 0.25 \\
\hline
\end{tabular}

observational days are shown. The scores, calculated against all available 3-hourly observations, are given in Table 2. Logically, the surface net radiation and the sensible heat flux are poorly simulated for each experiment due to the significant overestimation in shortwave and longwave radiations as well as in $2 \mathrm{~m}$ air temperatures. Conversely, the latent heat flux appears underestimated even if it is more reasonably simulated in PHY than in CTL. During September to October 2005, the evapotranspiration underestimation is due to the lack of simulated precipitation (see Figure 7). The same behavior appears in July 2006 while after the end of the WAM (October 2006), the overestimated precipitation leads to a simulation of more evapotranspiration than in observations. 

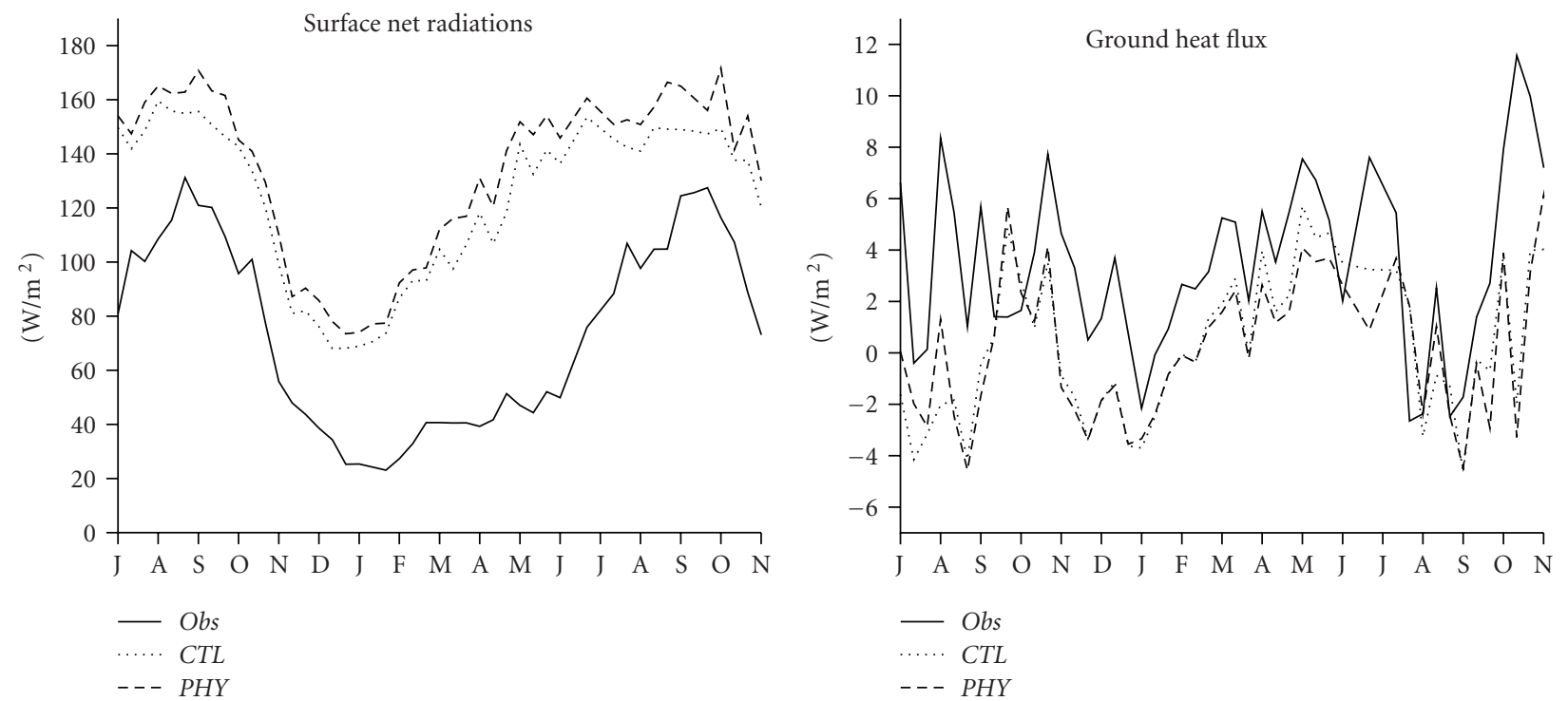

(a)
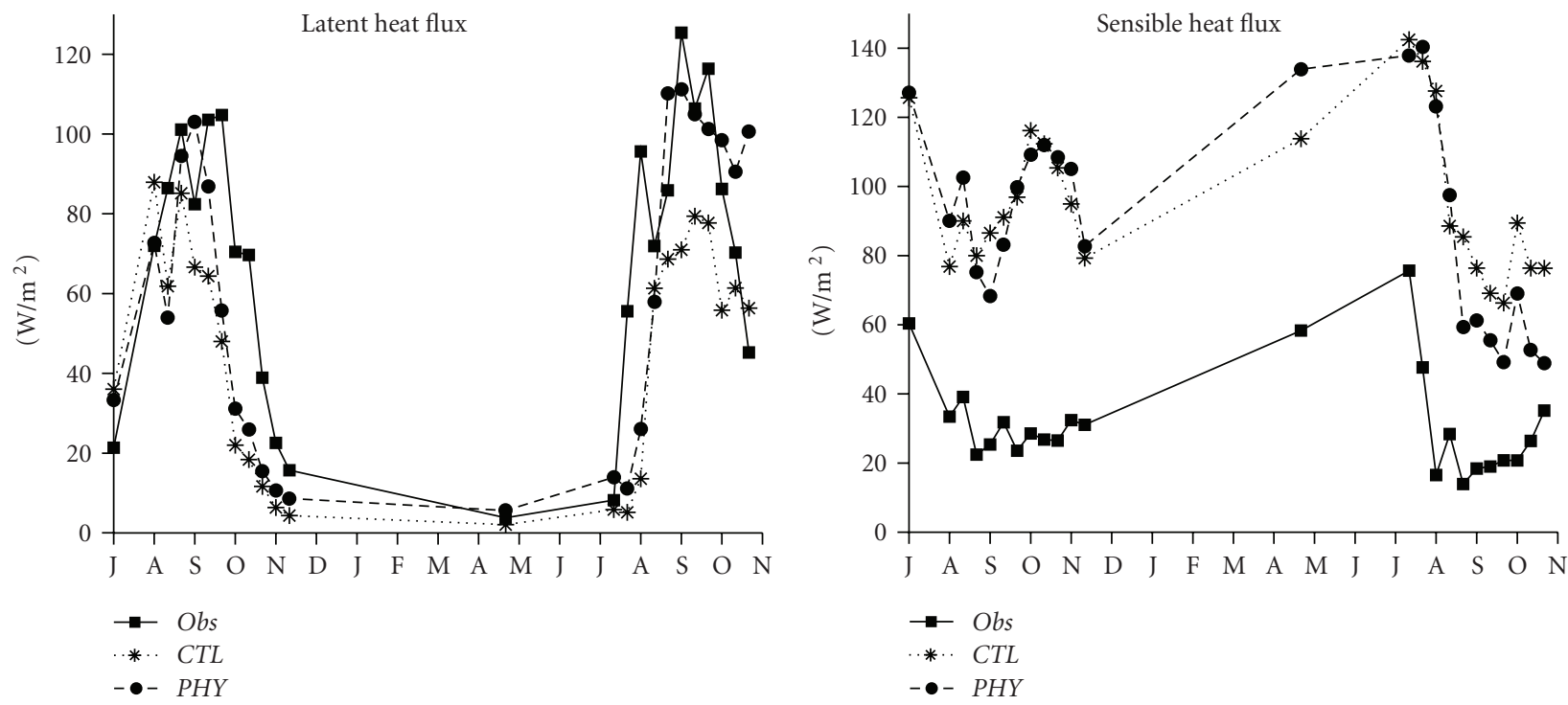

(c)

(d)

FIgURE 8: As in Figure 7 but for land surface energy budget variables averaged over a 10-day period. All related statistics are given in Table 2. Note that for the latent and sensible heat fluxes, each period were there is not enough day of observation $(<5$ days $)$ to perform an average have been removed.

\section{Discussion}

The evaluation of Noah-WRF against Wankama in situ measurements, which only represents a single grid cell of Dantiandou Kori (grid 3) in WRF, could appear debatable. However, it allows some interesting analyses with respect to the results found over the whole evaluation domain (grid 3 ). The combination of these results seems to show that a model warm bias is present in the simulations. The poor representation of dusts and aerosols within WRF is one possible reason because they drastically impact on the downward shortwave radiations [41] and then on the atmospheric radiative budget over West Africa. During the HAPEX-Sahel experiment situated over the same domain than the present study, Goutorbe et al. [29] point out the importance of a high level of aerosol concentration to perform a correct simulation of the global radiations at the surface. Other causes can be linked to some deficiencies into the Noah-WRF physical parameterizations as the underestimation in soil heat flux (Figure 8). Note that both Noah versions have been already tested at local scale over the Wankama measurements driven by the in situ atmospheric variables. Results have also shown a general underestimation in soil heat flux compared to observations. Further investigations will be done in a near future to improve this aspect. 
In 2005, the simulated and observed annual rates of precipitation are very close while the comparison of the simulated surface soil moisture with ASAR estimates shows that the model is relatively wet during the WAM. As it can be observed in Figure 6(a), this result seems to be in agreement with the significant soil moisture storage found in each experiment. Beside the uncertainties in ASAR data, this soil moisture overestimation can be partly due to an underestimation of the total evapotranspiration as it is found in the comparison against Wankama in situ measurements. Figure 6(a) shows that the vegetation evapotranspiration appears particularly small in all simulations compared to offline results from Saux-Picart et al. [27] obtained over the same Dantiandou Kori. The main cause is the small greenness vegetation fraction given by the NCEP FNL data in grid 3. This remark points out that the land cover map used in this study is certainly not realistic over Dantiandou Kori where millet and fallow fields dominate instead of grassland and savanna. This fact emphasizes the need to perform sensitive experiments to vegetation properties. The use of another database or remote sensing data could be very useful to reach this objective. For example, the SPOT/HRV images [27] or the MODIS data could be used to derive more realistic land cover maps and biomass dynamics which could help to define all the vegetation properties as well as the spatial and temporal variabilities. This remark could be applied to any regional climate modeling effort. Using static, climatological vegetation properties is a weakness of many climate applications. Finally, the poor distribution of the different vegetation types in the simulations, and then the poor representation of the surface albedo, can also play on the model warm bias.

Despite these limitations, the new land surface hydrology shows relative improvement of the model results in terms of precipitation, $2 \mathrm{~m}$ air temperature, relative humidity, total evapotranspiration, surface soil moisture, and surface temperature. These results confirm that the representation of the surface hydrology can impact on the surface fluxes and state variable simulated during the WAM by a coupled landatmosphere mesoscale model. Nevertheless, this conclusion must be taken with caution. Even if the studied area is constrained by the atmospheric lateral boundary conditions simulated by the two other domains that contribute to limit its own variability, mainly ensemble experiments with different land surface initial conditions, such as soil moisture and/or different meteorological conditions (clear sky and severe weather cases), will be able to confirm the real influence of this land surface hydrology on the Sahelian WAM simulated by WRF.

The choice of some parameterizations used in $P H Y$ is open to debate. A simple exponential profile of the saturated hydraulic conductivity with soil depth can appear unrealistic over the Sahel where the soil stratification is more complex. A more robust solution would be to replace the former homogeneous textural profile by a stratified soil [42]. Nevertheless, the main constraint for modelers is that soil textural vertical profile is poorly known over West Africa. In addition, the surface crust effect, which can lead to significantly decrease of the surface saturated hydraulic conductivity and then increase of Horton runoff, is not represented. It is well known that Horton runoff is the dominant process in these regions while in $P H Y$ it represents only $40 \%$ of the simulated total surface runoff (Dunne + Horton). The use of a "surface crust saturated hydraulic conductivity" instead of $k_{\text {sat }}(0)$ in (4) should improve this feature by favoring the Horton mechanism to the detriment of the Dunne runoff [43]. Accordingly, the use of a TOPMODEL approach is also open to debate because it is certainly more the spatial heterogeneities in soil characteristics, as the saturated hydraulic conductivity, which governs the genesis of surface runoff than the subgrid distribution of the topography.

\section{Conclusion}

This study focuses on the evaluation of a new land surface hydrology into the coupled Noah-WRF mesocale model for hydrological applications over the Sahel. A comparison between the previous version of the Noah land surface model and the new version are presented at high resolution $(3 \mathrm{~km})$ over Dantiandou Kori against a dense rain gauge network, satellite estimates of surface temperature and soil moisture, and in situ observations of atmospheric forcing and land surface water and energy variables.

Generally, the WAM is reasonably reproduced by the model even if some limitations appear throughout the comparison between simulations and observations. The simulated precipitation appears generally overestimated, especially concerning some extreme rainy events. However, the WAM period appears relatively well simulated by the model. The observations point out that 2006 is wetter in terms of precipitation than 2005. This finding is also well reproduced by the model but a warm bias is also found. Then, it impacts on the surface energy budget by overestimating downward shortwave radiation and consequently increasing net radiation, surface temperatures, and sensible heat fluxes, especially during the WAM. Consequently, this bias must be corrected to improve the simulated WAM over the Sahel with WRF. Further investigation should be made in the near futures using another radiative scheme that takes into account dust and aerosols and improving the representation of the soil heat flux.

The poor vegetation database in this study emphasises the need to develop alternative maps of vegetations properties using, for example, remote sensing products. This feature could be of primary importance to perform mesoscale-coupled studies in order to quantify the role of the vegetation on the Sahelian WAM dynamics. Furthermore, the land surface hydrology could be improved by adding the representation of a "soil surface crust" and accounting for soil characteristics heterogeneities which mainly control the surface runoff production over the Sahel.

Despite these limitations, the comparison between the former and the new land surface hydrology into WRF shows that Noah-SGH induces some relative improvements in terms of model performance. This new version of NoahWRF, under condition of some additional improvements, 
represents an interesting tool to perform mesoscale hydrological studies within land-atmosphere-coupled experiments over the Sahel.

\section{Acknowledgments}

The authors would like to thank all their colleagues at the many French and African laboratories that have participated in the development of the AMMA-CATCH experiment and particularly the Institut pour la Recherche et le Développement (IRD). Based on a French initiative, AMMA was built by an international scientific group and is currently funded by a large number of agencies, especially from France, UK, USA, and Africa. It is also the beneficiary of a major financial contribution from the European Community's Sixth Framework Research Programme. Detailed information on scientific coordination and funding is available on the AMMA International web site http://www.amma-international.org/. Access to data from the AMMA-Niger rainfall network is gratefully acknowledged. The partial support by the "Eau et Végétation au Niger" project of the French ECCO-PNRH program is also acknowledged. Thanks are also due to Mathieu Lelay (CNRM) and other anonymous reviewers for their constructive comments, as well as Arnaud Caubel (LSCE) for his computer support on the WRF model. The MSG-SEVIRI data were provided by the EUMETSATLand SAF via the POSTEL land surface thematic center (http://postel.mediasfrance.org/), and the ENVISAT-ASAR data were obtained thanks to ESA.

\section{References}

[1] J. G. Charney, "Dynamics of deserts and drought in the Sahel," The Quarterly Journal of the Royal Meteorological Society, vol. 101, pp. 193-202, 1975.

[2] C. M. Taylor, F. Said, and T. Lebel, "Interactions between the land surface and mesoscale rainfall variability during HAPEXSahel," Monthly Weather Review, vol. 125, no. 9, pp. 22112227, 1997.

[3] C. M. Taylor and T. Lebel, "Observational evidence of persistent convective-scale rainfall patterns," Monthly Weather Review, vol. 126, no. 6, pp. 1597-1607, 1998.

[4] H. Douville, "Influence of soil moisture on the Asian and African monsoons-part II: interannual variability," Journal of Climate, vol. 15, no. 7, pp. 701-720, 2002.

[5] R. D. Koster, P. A. Dirmeyer, Z. Guo, et al., "Regions of strong coupling between soil moisture and precipitation," Science, vol. 305, no. 5687, pp. 1138-1140, 2004.

[6] F. Chen and J. Dudhia, "Coupling an advanced land surfacehydrology model with the Pen State-NCAR MM5 modeling system-part I: model implementation and sensitivity," Monthly Weather Review, vol. 129, pp. 569-585, 2001.

[7] B. Decharme, "Influence of runoff parameterization on continental hydrology: comparison between the Noah and the ISBA land surface models," Journal of Geophysical Research D, vol. 112, no. 19, article D19108, 2007.

[8] B. Decharme, H. Douville, A. Boone, F. Habets, and J. Noilhan, "Impact of an exponential profile of saturated hydraulic conductivity within the ISBA LSM: simulations over the
Rhône basin," Journal of Hydrometeorology, vol. 7, no. 1, pp. 61-80, 2006

[9] Y.-L. Lin, R. D. Farley, and H. D. Orville, "Bulk parameterization of the snow field in a cloud model," Journal of Climate \& Applied Meteorology, vol. 22, no. 6, pp. 1065-1092, 1983.

[10] E. J. Mlawer, S. J. Taubman, P. D. Brown, M. J. Iacono, and S. A. Clough, "Radiative transfer for inhomogeneous atmosphere: RRTM, a validated correlated-k model for the long wave," Journal of Geophysical Research, vol. 102, no. D14, pp. 16 663$16682,1997$.

[11] J. Dudhia, "Numerical study of convection observed during the winter monsoon experiment using a mesoscale twodimensional model," Journal of the Atmospheric Sciences, vol. 46, no. 20, pp. 3077-3107, 1989.

[12] S.-Y. Hong and H.-L. Pan, "Nonlocal boundary layer vertical diffusion in a medium-range forecast model," Monthly Weather Review, vol. 124, no. 10, pp. 2322-2339, 1996.

[13] J. S. Kain and J. Kain, "The Kain-Fritsch convective parameterization: an update," Journal of Applied Meteorology, vol. 43, no. 1, pp. 170-181, 2004.

[14] E. K. Gilliland and C. M. Rowe, "A comparison of cumulus parameterization scheme in the WRF model," in Proceedings of the 87th AMS Annual Meeting \& 21 th Conference on Hydrology, p. 2.16, San Antonio, Tex, USA, 2007.

[15] M. B. Ek, K. E. Mitchell, Y. Lin, et al., "Implementation of the upgraded Noah land-surface model in the NCEP operational mesoscale Eta model," Journal of Geophysical Research, vol. 108, p. 8851, 2003.

[16] R. H. Brook and A. T. Corey, "Properties of porous media affecting fluid flow," Journal of Irrigation and Drainage Engineering, vol. 17, pp. 187-208, 1966.

[17] J. C. Schaake, V. I. Koren, Q.-Y. Duan, K. Mitchell, and F. Chen, "Simple water balance model (SWB) for estimating runoff at different spatial and temporal scales," Journal of Geophysical Research D, vol. 101, pp. 7461-7475, 1996.

[18] E. F. Wood, D. Lettenmaier, X. Liang, et al., "The project for intercomparison of land-surface parameterization schemes (PILPS) phase-2c Red-Arkansas River Basin experimentI: experiment description and summary intercomparison," Global and Planetary Change, vol. 19, pp. 115-135, 1998.

[19] J. F. Mahfouf and J. Noilhan, "Comparative study of various formulations of evaporation from bare soil using in situ data," Journal of Applied Meteorology, vol. 30, no. 9, pp. 1354-1365, 1991.

[20] I. Braud, J. Noilhan, P. Bessemoulin, P. Mascart, R. Haverkamp, and M. Vauclin, "Bare-ground surface heat and water exchanges under dry conditions: observations and parameterization," Boundary-Layer Meteorology, vol. 66, no. 12, pp. 173-200, 1993.

[21] K. J. Beven and M. J. Kirkby, "A physically-based variable contributing area model of basin hydrology," Hydrological Sciences Bulletin, vol. 24, no. 1, pp. 43-69, 1979.

[22] G. M. Saulnier and R. Datin, "Analytical solving of a bias in the TOPMODEL framework water balance," Hydological Processes, vol. 18, pp. 1195-1218, 2004.

[23] B. Decharme and H. Douville, "Global validation of the ISBA sub-grid hydrology," Climate Dynamics, vol. 29, no. 1, pp. 2137, 2007.

[24] F. Abramopoulos, C. Rosenzweig, and B. Choudhury, "Improved ground hydrology calculation for global climate models (GCMs): soil water movement and evapotranspiration," Journal of Climate, vol. 1, pp. 921-941, 1988.

[25] D. Entekhabi and P. S. Eagleson, "Land surface hydrology parameterization for atmospheric general circulation models 
including subgrid spatial variability," Journal of Climate, vol. 2, pp. 816-831, 1989.

[26] R. B. Clapp and G. M. Hornberger, "Empirical equations for some soil hydraulic properties," Water Resources Research, vol. 14, no. 4, pp. 601-604, 1978.

[27] S. Saux-Picart, C. Ottlé, B. Decharme, et al., "Water and energy budgets simulation over the AMMA-Niger super-site spatially constrained with remote sensing data," Journal of Hydrology, vol. 375, no. 1-2, pp. 287-295, 2009.

[28] D. Elizondo, B. Cappelaere, and C. Faure, "Automatic versus manual model differentiation to compute sensitivities and solve non-linear inverse problems," Computers and Geosciences, vol. 28, no. 3, pp. 309-326, 2002.

[29] J. P. Goutorbe, T. Lebel, A. J. Dolman, et al., "An overview of HAPEX-Sahel: a study in climate and desertification," Journal of Hydrology, vol. 188-189, no. 1-4, pp. 4-17, 1997.

[30] T. Lebel, H. Sauvageot, M. Hoepffner, M. Desbois, B. Guillot, and P. Hubert, "Rainfall estimation in the Sahel: the EPSATNIGER experiment," Hydrological Sciences Journal, vol. 37, no. 3, pp. 201-215, 1992.

[31] L. Descroix, G. Mahé, T. Lebel, et al., "Spatio-temporal variability of hydrological regimes around the boundaries between Sahelian and Sudanian areas of West Africa: A synthesis," Journal of Hydrology, vol. 375, no. 1-2, pp. 90-102, 2009.

[32] T. Vischel, Modélisation du cycle continental de l'eau à l'échelle régionale: impact de la modélisation de l'enneigement sur l'hydrologie du bassin versant du Rhône, Ph.D. thesis, Institu National Polytechnique, Grenoble, France, 2006.

[33] C. Madeira, P. Dash, F. Olesen, and I. Trigo, "Generalized splitwindow algorithm for retrieving land surface temperature from MSG/SEVIRI data," in Proceedings of the Land Surface Analysis SAF Training Workshop, Lisbon, Portugal, 2002.

[34] M. Zribi, S. Saux-Picart, C. André, L. Descroix, C. Ottlé, and A. Kallel, "Soil moisture mapping based on ASAR/ENVISAT radar data over a Sahelian region," International Journal of Remote Sensing, vol. 28, no. 16, pp. 3547-3565, 2007.

[35] B. Cappelaere, B.-E. Vieux, C. Peugeot, A. Maia, and L. Séguis, "Hydrologic process simulation of semiarid, endoreic catchment in Sahelien West Niger: 2. Model calibration and uncertainty characterization," Journal of Hydrology, vol. 279, pp. 244-261, 2003.

[36] C. Peugeot, B. Cappelaere, B. E. Vieux, L. Séguis, and A. Maia, "Hydrologic process simulation of a semiarid, endoreic catchment in Sahelian West Niger-1: model-aided data analysis and screening," Journal of Hydrology, vol. 279, no. 1-4, pp. 224-243, 2003.

[37] D. Ramier, N. Boulain, B. Cappelaere, et al., "Towards an understanding of coupled physical and biological processes in the cultivated Sahel-1: energy and water," Journal of Hydrology, vol. 375, no. 1-2, pp. 204-216, 2009.

[38] H. Gallée, W. Moufouma-Okia, P. Bechtold, et al., "A hightresolution simulation of West African rainy season using a regional climate model," Journal of Geophysical Research, vol. 109, article D05108, 2004.

[39] S. Sijikumar, P. Roucou, and B. Fontaine, "Monsoon onset over Sudan-Sahel: simulation by the regional scale model MM5," Geophysical Research Letters, vol. 33, no. 3, article L03814, 2006.

[40] J. E. Nash and J. V. Sutcliffe, "River flow forecasting through conceptual models-part 1: a discussion of principales," Journal of Hydrology, vol. 10, pp. 282-290, 1970.

[41] N. Hatzianastassiou, C. Matsoukas, and E. Drakakis, "The direct effect of aerosols on solar radiation based on satellite observation, reanalysis datasets, and spectral aerosol opticalk properties from Global Aerosol Data Set (GADS)," Atmospheric Chemistry and Physics, vol. 7, pp. 2585-2599, 2007.

[42] N. Montaldo and J. D. Albertson, "On the use of the forcerestore SVAT model formulation for stratified soils," Journal of Hydrometeorology, vol. 2, no. 6, pp. 571-578, 2001.

[43] T. Pellarin, J. P. Laurent, B. Cappelaere, B. Decharme, L. Descroix, and D. Ramier, "Hydrological modelling and associated microwave emission of a semi-arid region in Southwestern Niger," Journal of Hydrology, vol. 375, no. 1-2, pp. 262272,2009 . 

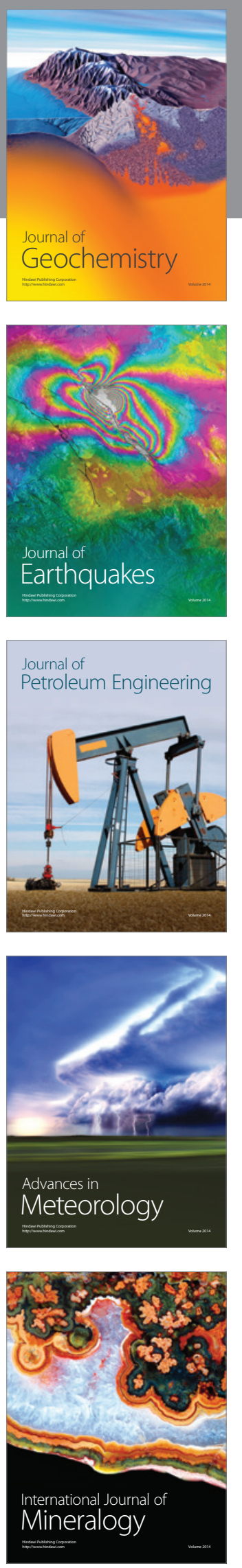
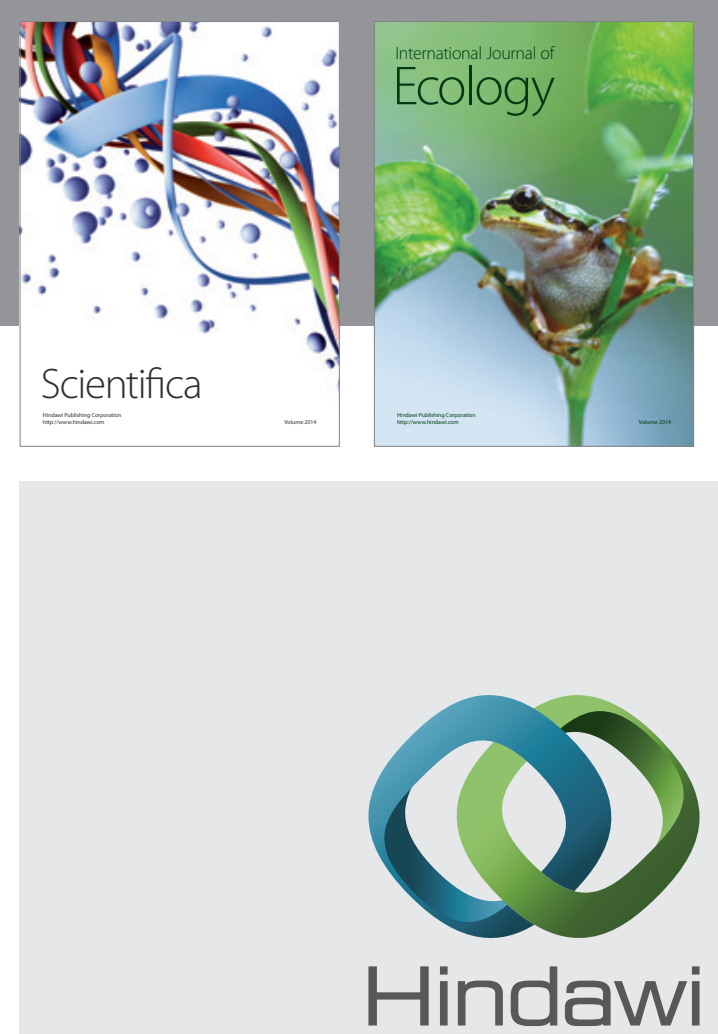

Submit your manuscripts at http://www.hindawi.com
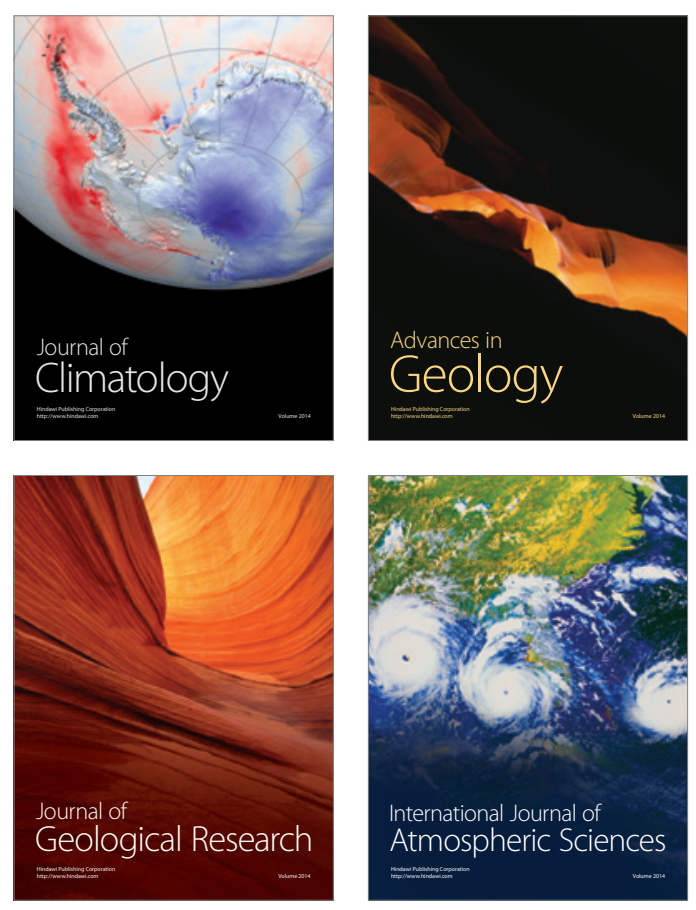
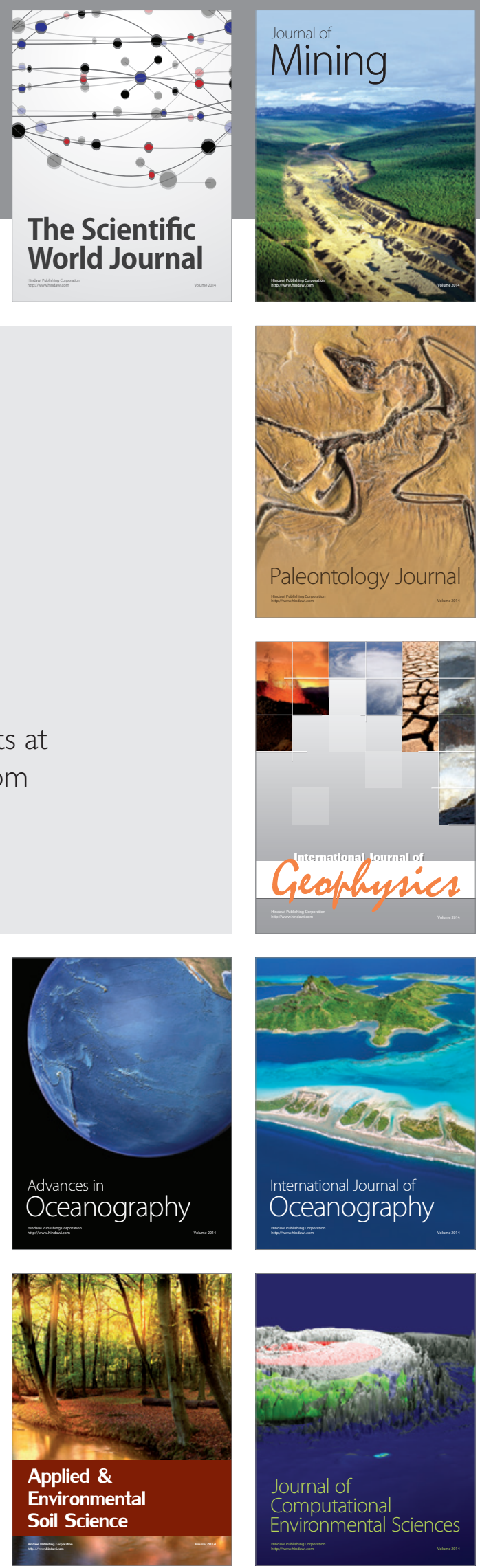